\title{
GUSTAV TAMMANN, KURROLI SOOL JA POLUMEERSED FOSFAADID
}

Kuni XIX sajandi alguseni tunti ja kirjeldati praktiliselt vaid tavalist fosforhapet ja selle soolasid - fosfaate, mida praegusaegse nomenklatuuri järgi nimetatakse vastavalt monofosforhappeks ja monofosfaatideks. 1816. aastal aga sai Jacob Berzelius fosforhappe kuumutamisel ühendi, mis erines omadustelt lähteainest. Kogunud kokku olemasoleva materjali fosfaatide kohta ja toetudes Berzeliuse seisukohtadele, mille järgi hapnikhapete soolad on väljendatavad vastavate aluseliste ja happeliste oksiidide kaudu, jagas Thomas Graham 1833.-1834. aastal fosfaadid kolme rühma - orto-, püro- ja metafosfaatideks, millel on vastavalt järgmised valemid ( $M$ on metall olekus oksüdatsiooniastmega $I$, vesiniksoolades ka vesinik): $3 \mathrm{M}_{2} \mathrm{O} \cdot \mathrm{P}_{2} \mathrm{O}_{5}$ e. $\mathrm{M}_{3} \mathrm{PO}_{4}$

$2 \mathrm{M}_{2} \mathrm{O} \cdot \mathrm{P}_{2} \mathrm{O}_{5}$ e. $\mathrm{M}_{4} \mathrm{P}_{2} \mathrm{O}_{7}$

$\mathrm{M}_{2} \mathrm{O} \cdot \mathrm{P}_{2} \mathrm{O}_{5}$ e. $\left(\mathrm{MPO}_{3}\right)_{\mathrm{n}}$.

Kuumutades $\mathrm{NaH}_{2} \mathrm{PO}_{4} \quad 620^{\circ}$-ni ja sulasaadust kiiresti jahutades sünteesis Graham klaasja naatriummetafosfaadi, mida seniajani nimetatakse Grahami soolaks, sageli ebaōigesti ka naatriumheksametafosfaadiks. Kuumutades $\mathrm{NaH}_{2} \mathrm{PO}_{4} 240^{\circ}$-ni sai Graham sama koostisega mittelahustuva kristalse soola. Kuna selle sai analoogselt 1847. aastal ka R. Maddrell, siis hakati seda soola hiljem nimetama viimase järgi.

Erinevalt Grahamist väitsid 1845.-1849. aastal T. Fleitmann ja W. Henneberg, et ortofosfaatidest erinevad fosfaadid moodustavad ühendite rea, milles neid võib kujutada selliste hapete sooladena, mis on saadud ortofosforhappest vee järkjärgulise eraldamise teel, s. o. $\mathrm{H}_{4} \mathrm{P}_{2} \mathrm{O}_{7}, \mathrm{H}_{5} \mathrm{P}_{3} \mathrm{O}_{10}$, $\mathrm{H}_{6} \mathrm{P}_{4} \mathrm{O}_{13}$ jne. ehk üldvalemina $\mathrm{mH}_{3} \mathrm{PO}_{4}-(\mathrm{m}-1) \mathrm{H}_{2} \mathrm{O}$. Esialgu jäid aga püsima Grahami seisukohad, fosfaatide homoloogilise rea olemasolusse suhtuti kuni 1940. aastateni skeptiliselt [1, 2].

Seni oli suhteliselt vähe teada, et 1880 . aastate loppul hakkas metafosfaate intensiivselt uurima Tartu ülikooli keemiakateedri laborant, hilisem sama kateedri juhataja (1892-1902) ja maailmakuulus füsikokeemik Gustav Tammann $(1861-1938)$. Toetudes Jacobus van't Hoffi ja Svante Arrheniuse poolt avastatud seaduspärasustele lahuste kohta ning kasutades krüoskoopilist meetodit ja elektrijuhtivuse mõōtmist koos keemilise analüüsi andmetega, tegi ta oma abilistega ära mahuka uurimistöö. Varieerides lähteaineid $\mathrm{ja}$ sünteesimeetodeid valmistati ja uuriti üle 40 metafosfaadi, sealhulgas rohkesti kaksiksooli. Määrati nende koostist, lahustuvust ja dissotsiatsiooni, molaarmasse, arvutati välja ühendite valemid. Sünteeside kestus ulatus teinekord nädalate ja kuudeni, tööst vôttis osa mitmeid kateedri töötajaid ja üliōpilasi, kelledest kuut mainib Tammann oma publikatsioonides nimeliselt. 
Saadud metafosfaadid haarasid ühendite rida naatriumdimetafosfaadist $\left(\mathrm{NaPO}_{3}\right)_{2}$ kuni magneesiumnaatriumtetradekametafosfaadini $\mathrm{Mg}_{6} \mathrm{Na}_{2}\left(\mathrm{PO}_{3}\right)_{14}$. Kui varem oli tõestatud vaid vesiniku ja kahevalentsete metallide esinemist anioonsete kompleksioonide koostises, siis Tammann väitis leelismetallide metafosfaatide alusel, et ka need võivad kuuluda anioonsetesse kompleksidesse, näiteks ühendites $\mathrm{Na}_{2}\left[\mathrm{Na}_{4}\left(\mathrm{PO}_{3}\right)_{6}\right]$ ja $\mathrm{Na}_{4}\left[\mathrm{Na}_{2}\left(\mathrm{PO}_{3}\right)_{6}\right]$, mis vesilahuses annavad vastavalt $\left[\mathrm{Na}_{4}\left(\mathrm{PO}_{3}\right)_{6}\right]^{2-}$ - ja $\left[\mathrm{Na}_{2}\left(\mathrm{PO}_{3}\right)_{6}\right]^{4-}$-ioone. Tammann sünteesis ka ühendid, mis vastavat naatriumdi- ja naatriumtrimetafosfaatidele $\left(\mathrm{NaPO}_{3}\right)_{2},\left(\mathrm{NaPO}_{3}\right)_{3}$.

Ammooniumpentametafosfaadi ja leelismetallide halogeniidide lahuste vastastikusel toimel sai ta sooli, milledes viiest ammooniumrühmast neli asendus leelismetallidega $-\mathrm{NH}_{4} \mathrm{~K}_{4}\left(\mathrm{PO}_{3}\right)_{5}, \mathrm{NH}_{4} \mathrm{Na}_{4}\left(\mathrm{PO}_{3}\right)_{5}, \mathrm{NH}_{4} \mathrm{Li}_{4}\left(\mathrm{PO}_{3}\right)_{5}$. Selle põhjal andis ta lähtesoolale valemi $\mathrm{NH}_{4}\left[\left(\mathrm{NH}_{4}\right)_{4}\left(\mathrm{PO}_{3}\right)_{5}\right]$. Vaatamata koostise sarnasusele käituvad need soolad lahustes erinevalt. Kui $\mathrm{NH}_{4} \mathrm{~K}_{4}\left(\mathrm{PO}_{3}\right)_{5}$ dissotseerub mõõduka lahjenduse korral kuueks iooniks

$$
\mathrm{NH}_{4} \mathrm{~K}_{4}\left(\mathrm{PO}_{3}\right)_{5}=\mathrm{NH}_{4}^{+}+4 \mathrm{~K}^{+}+\left(\mathrm{PO}_{3}\right)_{5}^{5-} \text {, }
$$

siis lähtesool annab vaid kaks iooni

$$
\mathrm{NH}_{4}\left[\left(\mathrm{NH}_{4}\right)_{4}\left(\mathrm{PO}_{3}\right)_{5}\right]=\mathrm{NH}_{4}^{+}+\left[\left(\mathrm{NH}_{4}\right)_{4}\left(\mathrm{PO}_{3}\right)_{5}\right]^{-} .
$$

Vaid lõpmata suure lahjenduse korral dissotseerub viimane analoogselt $\mathrm{NH}_{4} \mathrm{~K}_{4}\left(\mathrm{PO}_{3}\right)_{5}$-ga.

Sulatades kahevalentsete metallide sulfaate või kloriide koos naatriumammooniumvesinikfosfaatidega saadi sulatise jahutamisel oktametafosfaate üldvalemiga $\mathrm{M}_{3} \mathrm{Na}_{2}\left(\mathrm{PO}_{3}\right)_{8}$ (kui $\mathrm{M}=\mathrm{Mg}, \mathrm{Mn}, \mathrm{Co}, \mathrm{Zn}, \mathrm{Ni}$ ) vōi pürofosfaate $\mathrm{M}_{4} \mathrm{Na}_{4}\left(\mathrm{P}_{2} \mathrm{O}_{7}\right)_{3}(M=\mathrm{Ba}, \mathrm{Pb}, \mathrm{Cu})$. Kahevalentsete metallide sulfaatide, fosforhappe ja naatriumdivesinikfosfaadi kuumutamisel sai Tammann ühendeid, mida ta iseloomustas kui tetradekametafosfaate $\mathrm{M}_{6} \mathrm{Na}_{2}\left(\mathrm{PO}_{3}\right)_{14}$.

Tammann näitas, et Grahami sool pole ühtne ühend, vaid sisaldab mitmeid metafosfaate, mis dissotseerudes vesilahustes annavad erinevaid ioone - $\left(\mathrm{PO}_{3}\right)_{6}^{6-},\left[\mathrm{Na}_{4}\left(\mathrm{PO}_{3}\right)_{6}\right]^{2-},\left[\mathrm{Na}_{2}\left(\mathrm{PO}_{3}\right)_{6}\right]^{4-},\left[\mathrm{Na}\left(\mathrm{PO}_{3}\right)_{6}\right]^{5-}$. Hoides Grahami soola kontaktis $\mathrm{KCl}$ ja $\mathrm{NH}_{4} \mathrm{Cl}$ küllastatud lahustega õnnestus Tammannil aastase katsekestuse juures kogu naatrium välja vahetada kaaliumi või ammooniumiga ja saada lōpptulemuseks $2 \mathrm{KPO}_{3} \cdot 3 \mathrm{H}_{2} \mathrm{O}$ ja $10 \mathrm{NH}_{4} \mathrm{PO}_{3} \cdot 12 \mathrm{H}_{2} \mathrm{O}$. Uhtlasi sadestas Tammann Grahami soola lahusest $\mathrm{K}_{2} \mathrm{H}_{2} \mathrm{Sb}_{2} \mathrm{O}_{7}$ abil välja kogu naatriumi $\mathrm{Na}_{2} \mathrm{H}_{2} \mathrm{Sb}_{2} \mathrm{O}_{7}$-na.

Gustav Tammanni abiline Kurrol veetustas aeglase kuumutamise teel $\mathrm{NaH}_{2} \mathrm{PO}_{4}$ ning fikseeris seejuures mitu faasiüleminekut: kõigepealt soola sulamise, seejärel sulami tardumise «portselanitaoliseks» massiks, edasisel temperatuuri tõstmisel uuesti sulamise. «Portselanitaolise» massi nii nagu ka lōppsulatise aeglase jahutamise saaduse leostamisel veega jäi järele vees lahustumatu kristalne jääk valemiga $\left(\mathrm{NaPO}_{3}\right)_{n}$, mis lahustus leelismetallide soolade lahustes. Tammanni määramiste järgi saadud soolas $\mathrm{n}=12,48 \mathrm{ja} 96$, kontaktis $\mathrm{AgNO}_{3}$ lahusega on üks naatriumi aatom nendes asendatav hõbeda aatomiga.

Näidates metafosfaatide suurt mitmekesisust järeldab Tammann metafosfaatide rea olemasolu, mis pole palju vaesem etüleenireast. Nagu viimaseski esinevad selles nii isomeeria kui ka polümeeria nähtused - mõlemad metameeria liigid, nagu neid Berzeliuse järgi nimetab ka Tammann. Kui etüleenirea ühendite erinevusi seletati struktuuri muutustega ja stereokeemia printsiipidega, siis metafosfaatides on need Tammanni arvates seletatavad elektrokeemia seadustega.

Tammanni uurimused olid aluseks tema doktoridissertatsioonile «Metafosfaatide metameeriast», mida ta kaitses Tartu ülikoolis 1890. aastal. 
Ametlikeks oponentideks olid seejuures professorid Johann Lemberg, Arthur von Oettingen ja Carl Schmidt [ ${ }^{3}$. Uurimuste tulemused avaldas ta artiklitena 1890. - aastal «Füüsikalise Keemia Ajakirjas» ja pōhjalikumalt 1892. aastal «Praktilise Keemia Ajakirjas» [4-5].

Tammanni publikatsioonid metafosfaatidest äratasid fosfaatide uurijates laialdast tähelepanu, neid tsiteeritakse erialases kirjanduses tänapäevani. Toetudes põhiliselt elektrokeemia printsiipidele ei suutnud Tammann uurimismeetodite piiratuse tõttu veenvalt pōhjendada, miks sama koostisega, kuid eri meetoditel saadud metafosfaadid on erinevate omadustega. Ammendav vastus sellele anti alles alates 1950. aastatest, kui uuringutel kasutati spektroskoopiat, röntgendifraktsiooni, kromatograafiat ja teisi meetodeid. Mitmed Tammanni seisukohad osutusid hiljem ebatäpseks või ekslikuks, näiteks kontseptsioon metafosfaatide anioonkompleksidest, naatriumdimetafosfaadi ja mõnede teiste metafosfaatide olemasolu jm., kuid ta andis rikkalikult alusmaterjali edasisteks uurimusteks, tõuke polümeersete fosfaatide teooria arengule.

Kuna edasiste uurimistööde objektiks olid eeskätt leelismetallide metafosfaadid, siis leidis ka Tammanni uurimustest kõige suuremat vastukaja just nendele pühendatud osa. Eelkõige puutub see sulatisest saadud niitjate kristallidega naatriummetafosfaati, mida hakati esmasünteesija järgi nimetama Kurroli soolaks. Kurroli ja Maddrelli soolade omaduste erinevust ja struktuuri käsitletakse vähemalt 50 publikatsioonis, nendele on pühendatud J. van Wazeri monograafia ['] terve peatükk, neid kirjeldatakse ka hilisemates monograafiates fosfaatidest $\left[{ }^{2,}{ }^{6}\right]$ ning üldlevinud KirkOthmeri ja Ullmanni keemilise tehnoloogia entsüklopeediates, samuti Gmelini anorgaanilise keemia käsiraamatus. Kurroli soola süntees on antud ka hiljuti ilmunud kapitaalses anorgaanilise sünteesi käsiraamatus [ $\left.{ }^{7}\right]$. Sealjuures on Kurroli enda isik senini jäänud tundmatuks,-temalt pole ilmunud ühtegi publikatsiooni. Vaid tänu Tammanni kõrgetele eetilistele tõekspidamistele ja korrektsusele oma abiliste nimetamises on Kurroli nimi läinud fosforikeemia ajalukku. Kurroli soola nimetust on nüüd laiendatud ka teistele analoogselt saadud kristalsetele, vees mittelahustuvatele leelismetallide ja ammooniummetafosfaatidele, mis leelismetallide teise soola manulusel siiski lahustuvad.

Käesoleval ajal hakkab metafosfaatide termin kui ebamäärane kõrvale jääma. Teda kasutatakse teinekord vaid nende polümeersete fosfaatide tähistamiseks, mille koostises molaarsuhe $\mathrm{M}_{2}^{\mathrm{I}} \mathrm{O}: \mathrm{P}_{2} \mathrm{O}_{5}$ on ligikaudu võrdne ühele, sõltumata struktuurist. Polümeersed ehk kondenseeritud fosfaadid liigitatakse nüüd kolme klassi sõltuvalt $\mathrm{PO}_{4}$-tetraeedrite liitumise tüübist nende tippudes olevate hapniku aatomite kaudu. Kui seejuures korduvad -P-O-P- grupid moodustavad ahelstruktuuri, nimetatakse neid polüfosfaatideks (üldvalemiga $\mathrm{M}_{\mathrm{n}+2}^{\mathrm{I}} \mathrm{P}_{\mathrm{n}} \mathrm{O}_{3 \mathrm{n}+1}$, milles $\mathrm{n}^{\mathrm{I}}=2 \div \infty$ ), kui moodustavad ringstruktuuri, siis tsüklofosfaatideks $\left(M_{n} P_{n} O_{3 n}\right.$, milles seniste andmete järgi $\mathrm{n}=3 \div 8$ ), kui aga ruumis hargnenud ahelaid, milledes $\mathrm{PO}_{4}$-tetraeedrid on liitunud kolme hapniku aatomi kaudu, nimetatakse neid ultrafosfaatideks. Kui polüfosfaatides polümerisatsiooniaste tugevasti kasvab, s. o. kui $\mathrm{n} \rightarrow \infty$, siis ka molaarsuhe $\mathrm{M}_{2}^{\mathrm{I}} \mathrm{O}: \mathrm{P}_{2} \mathrm{O}_{5} \rightarrow 1$. Seega nn. metafosfaadid võivad kuuluda nii polüfosfaatide kui ka tsüklofosfaatide hulka, sageli aga koosneda nende segust.

Tänapäevaste teadmiste alusel kujutab Kurroli sool endast kōrgmolekulaarset kristalset polüfosfaati, milles sõltuvalt sünteesi tingimustest n võib omada väärtust mõnest sajast kuni mõnekümne tuhandeni. Kurroli sool erineb Maddrelli soolast korduvate struktuurifragmentide $\left(\mathrm{PO}_{4}\right.$ tetraeedrite) spiraalse paigutusega ahelas, seejuures eristatakse kaht tema erivormi (vt. joonis)[ ${ }^{2}$ ]. Kurroli soola lähem iseloomustus on esitatud eespool nimetatud J, van Wazeri monograafias. 


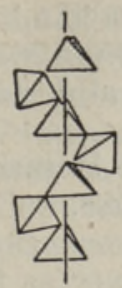

Kurroli. sool $A$

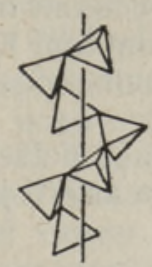

Kurroli sool B

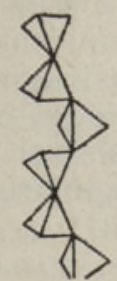

Maddrelli sool

Polümeersete fosfaatide süntees üldjuhul ei toimu ühes astmes, vaid rea vaheastmete kaupa, misjuures võivad moodustuda fosfaatide keerukad segud. Näiteks paberkromatograafia andmetel $\mathrm{Ca}\left(\mathrm{H}_{2} \mathrm{PO}_{4}\right)_{2} \cdot \mathrm{H}_{2} \mathrm{O}$ termilise dehüdratatsiooni vahe- ja lõppsaaduse koostist iseloomustab tabel $\left.{ }^{8}\right]$. Lõppsaaduse koostise ja struktuuri määravad põhiliselt katioonse komponendi fosfaataniooni suhe segus ja sünteesi tingimused.

$\mathrm{Ca}\left(\mathrm{H}_{2} \mathrm{PO}_{4}\right)_{2} \cdot \mathrm{H}_{2} \mathrm{O}$ kuumutamise saaduste koosseis, massi \% $\mathrm{P}_{2} \mathrm{O}_{5}$

\begin{tabular}{|c|c|c|c|c|c|c|c|c|c|c|c|c|}
\hline $\begin{array}{c}\text { Fos- } \\
\text { faadi } \\
\text { vorm, } \\
\text { kuu- } \\
\text { muta- } \\
\text { mis- } \\
\text { tem- } \\
\text { pera- } \\
\text { tuur }{ }^{\circ} \mathrm{C}\end{array}$ & mono- & di- & $\begin{array}{c}\text { tri- } \\
\text { polü }\end{array}$ & $\begin{array}{l}\text { tetra- } \\
\text { polü }\end{array}$ & $\begin{array}{l}\text { penta- } \\
\text { polü }\end{array}$ & $\begin{array}{c}\text { heksa- } \\
\text { polü }\end{array}$ & $\begin{array}{l}\text { hepta- } \\
\text { polü }\end{array}$ & $\begin{array}{l}\text { okta- } \\
\text { polü }\end{array}$ & $\begin{array}{l}\text { polü } \\
\mathrm{n}>8\end{array}$ & $\begin{array}{c}\text { tri- } \\
\text { tsüklo }\end{array}$ & $\begin{array}{l}\text { tetra- } \\
\text { tsüklo }\end{array}$ & $\begin{array}{l}\text { penta- } \\
\text { tsüklo }\end{array}$ \\
\hline $\begin{array}{l}300 \\
500\end{array}$ & $\begin{array}{l}5,79 \\
1,98\end{array}$ & 11,70 & $\begin{array}{r}13,12 \\
1,43\end{array}$ & $\stackrel{9,77}{-}$ & $\begin{array}{l}7,84 \\
0,76\end{array}$ & $\stackrel{4,89}{-}$ & $\underline{4,37}$ & 4,11 & $\overline{53,41}$ & $\begin{array}{l}1,54 \\
0,16\end{array}$ & $\underline{0,38}$ & 0,19 \\
\hline
\end{tabular}

Neid varieerides on võimalik valmistada etteantud omadustega spetsiifilisi materjale, mida saab kasutada reguleeritud lahustuvusega polümeersete väetistena, kuumuskindlate sideainetena, spetsiaaloptikas ja -keraamikas, lasermaterjalina, korrosioonikaitses, pesemisvahendite koostises, lisandainena parfümeeria- ja toiduainetööstuses ja mujal. Ka elusorganismide rakud sisaldavad polüfosfaate, mis etendavad olulist osa nende aine- ja energiavahetuses ning metabolismi reguleerimises [ ${ }^{9}$ ]. Võime julgesti väita, et Tartu ülikool ja Gustav Tammann ning tema koolkond on andnud olulise panuse polümeersete fosfaatide keemiasse.

Mida on praegu teada ainukese Eestist pärineva nimelise soola sünteesija kohta? Eesti NSV Riikliku Ajaloo Keskarhiivi andmetel [ $\left.{ }^{10}\right]$ sündis Julius Heinrichi p. Kurrol 1865. aastal Pärnus ametnikuperekonnas. 1876-1883 õppis ta Pärnu Gümnaasiumis, 1883 astus Tartu ülikooli füüsika-matemaatikateaduskonda. 1888 pöördus Kurrol ülikooli valitsuse poole palvega lubada sooritada kandidaadieksamid, kuid vabastada teda eksamimaksudest majanduslikel põhjustel. 1888-1890 sooritab Kurrol eksamid anorgaanilises keemias, analüütilises keemias, füsioloogilises keemias ja agrokeemias, orgaanilises keemias, tehnoloogias ja stöhhiomeetrias, tehnoloogilises keemias, kristallograafias ja mineraloogias, füüsikas, teoreetilises füüsikas, mehanilises soojusteoorias, kõrgemas matemaatilises analüüsis ja analüütilises geomeetrias ning teeb eksamitöö tundmatu aine analüüsis. Nendest kaks teeb ta hindele hea, ülejäänud hindele väga hea, sealhulgas ka viimati mainitud eksamitöö, hinnatuna 
Carl Schmidti poolt. 1891 kaitseb ta edukalt oma kandidaaditööd «Beiträge zur Kenntniss des unlöslichen Natrium und Kalium Metaphosphate» («Töö lahustumatutest naatrium- ja kaaliummetafosfaatidest»). Tema edasise elu kohta pole seni midagi teada.

Autor tänab professor Uno Palmi ja dotsent Heinrich Vilbokki kaasabi eest materjalide kogumises käesoleva artikli jaoks.

\section{K I R J A N D US}

1. Wazer, J. van. Phosphorus and its Compounds, 1. New York, 1958.

2. Corbridge, D. E. C. Phosphorus. Amsterdam-Oxford, et al., 1978.

3. Tammann, G. Ueber die Metamerie der Metaphosphate. - In: Eine zur Erlangung des Grades eines Doctors der Chemie der physiko-matematischen Facultät der Kaiserlichen Universität Dorpat. Dorpat, 1890.

4. Tammann, G. Ober die Isomerie der Metaphosphate. - Z phys. Chem., 1890, 6, $122-$ 140.

5. Tammann, G. Beiträge zur Kenntniss der Metaphosphate. - J. prakt. Chem., 1892, $45,417-474$.

6. Кузьменьков М. И., Печковский В. В., Плышевский С. В. Химия и технология метафосфатов. Минск, 1985.

7. Руководство по неорганическому синтезу. Ред. Г. Брауер. Т. 2. М., 1985.

8. Вейдерма М. А., Пылдме Ю. Х. Состав продуктов термической дегидратации монокальцийфосфата. - Ж. неорган. хим., 1976, 21, № 1, 10-15.

9. Кулаев H. С. Биохимия высокомолекулярных полифосфатов. М., 1975.

10. Eesti NSV Riiklik Ajaloo Keskarhiiv, f. 402, nim. 2, s. 13981, 13982.

Tallinna Polütehniline Instituut
Toimetusse saabunud 26. V 1986

У. ПАЛЬМ

\section{М. В. ЛОмоносов и ЭСтония (к 275-летию со дня рождения)}

В сущности все стороны многогранной научно-просветительской и литературной деятельности крупнейшего русского ученого-энциклопедиста Михаила Васильевича Ломоносова (1711-1765) нашли основательную научную разработку и освещение в трудах целой армии исследователей, специалистов в разных областях как науки и техники, так и литературы. Написаны десятки научных биографий Ломоносова, среди которых самой основательной следует считать монографию известного химика Б. Н. Меншуткина «Жизнеописание Михаила Васильевича Ломоносова» (1937) [1] - плод более чем 30-летних исследований. Роль Ломоносова в развитии химии впервые была убедительно доказана именно Б. Н. Меншуткиным в 1904 г. [2]. Им первым были переведены написанные на латинском языке труды Ломоносова на русский язык. Кстати, интересно отметить, что как Б. Н. Меншуткин, так и его отец, крупный русский химик Н. А. Меншуткин (1842-1907), поддерживали тесные связи с профессорами химии Тартуского университета. Так, например, доцент химии (впоследствии профессор Воронежского и Тартуского (Юрьевского) университетов) А. Д. Богоявленский (1868-1941) был освобожден из тюрьмы в революционные 1905-1906 гг. только благодаря специальному визиту Н. А. Меншуткина тогдашнему министру внутренних дел (и председателю Совета министров) П. А. Столыпину [3]. В библиотеке химического отделения ТГУ хранятся труды 
Б. Н. Меншуткина с дарственными подписями автора профессору химии университета Г. Ландезену (1867-1935).

Одним из первых биографов М. В. Ломоносова как химика был и профессор химии Рижского политехнического института, академик Петербургской Академии наук П. Вальден (1863-1957), ученик воспитанника Тартуского (Дерптского) университета, одного из основоположников современной физической химии В. Освальда (1853-1932), высоко оценившего в своей научно-литературной деятельности роль Ломоносова в развитии химии, в частности физической химии [4]. По имеющимся данным, доцент геологии В. В. Богачев (1881-1965) первым из преподавателей Тартуского университета глубоко изучил труды Ломоносова по геологии и минералогии, а также по химии и опубликовал в 1912 г. статью «Ломоносов - первый русский геолог» [5]. В 1911 г. в Тартуском университете было торжественно отмечено 200-летие со дня рождения Ломоносова. Однако перечисленные выше единичные примеры явились лишь поздними откликами на те прямые связи, которые установились во время жизни Ломоносова с Эстонией и Прибалтикой в целом. В данной статье несколько подробнее проследим связи Ломоносова с нашим краем, относительно скромно отраженные в литературе о нем. В этих связях можно выделить четыре основных аспекта: формирование молодого Ломоносова как будущего самобытного ученого; научное исследование различных природных богатств Эстонии; его прямые контакты с учеными, происходившими из Прибалтики; и наконец, роль здешних культурных центров и ученых в опубликовании трудов Ломоносова и развитии его научного наследия. Ниже попытаемся показать роль этих связей в развитии научных концепций Ломоносова вообще.

Как правило, при формировании мировоззрения молодого ученого наряду с социально-политическими факторами решающую роль играет как царящая в данную эпоху в области научной методологии общая атмосфера, так и та конкретная научная среда, в которой будущий ученый учится и начинает свою деятельность. На всем творчестве Ломоносова отразилось влияние острого в 18 столетии противоборства двух научных методологий - картезианской (сторонники философа Декарта) и ньютоновой. Картезианцы признавали за материей только простейшие геометрические и механические качества, всякое взаимодействие они сводили к непосредственному толчку или давлению и не признавали никакого действия на расстояние. Они исходили из выдвинутой гипотезы и мало полагались на опыт. Напротив, Ньютон и его сторонники отказались от заранее принятых принципов и гипотез и опирались на математические обобщения экспериментально установленных фактов. Ньютон ввел в науку понятие мгновенно действующих на расстояние сил (гравитационных, электрических, магнитных и т. д.). Как мы увидим далее, оригинальные научные концепции Ломоносова содержат элементы как одного, так и другого подхода.

М. В. Ломоносов начал свое образование в 1731 году в Московской Славяно-греко-латинской академии, где проучился почти 6 лет. Там он получил глубокие знания по классическим языкам, там пробудился у него интерес к литературно-поэтическому творчеству и выработалось глубокое неприятие схоластики как метода рассуждения. В 1736 г. он в течение восьми месяцев продолжал образование в Петербурге в Академическом университете, где в то время преподавали крупные математики и физики своего времени, в основном картезианцы. Нет сомнения, что атмосфера университета оказала большое влияние на формирование интересов и взглядов молодого Ломоносова, который там особенно увлекался математикой, поэзией, минералогией и физическими эксперимеңтами [6]. Химия как наука в Академии почти не была представлена.

В те годы президентом Петербургской Академии наук был выходец 
из Курляндии И. А. Корф (1697-1766), придворный курляндской герцогини Анны Иоанновны, дочери единокровного брата Петра I, занимавшей русский престол в 1730-1740 гг. И. А. Корф обратил внимание на исключительно одаренного и трудолюбивого юношу и командировал М. В. Ломоносова в Германию, где он и завершил свое образование в Марбургском и Фрейбергском университетах.

И. А. Корф собственноручно составил инструкцию для Ломоносова, в которой была подчеркнута необходимость глубокого изучения горного дела, химии, естественной теории, физики, геометрии, механики, гидравлики и гидротехники. Этот документ свидетельствует о решимости И. А. Корфа реализовать дальновидную стратегию Петра I относительно подготовки для России отечественных научных и инженерных кадров [7]. Кстати, прямым толчком к направлению нескольких талантливых молодых русских в университеты Запада послужило письмо академика И. Гмелина из Камчатской экспедиции, в котором он со всей серьезностью указывал на необходимость подготовки русских горных специалистов для освоения огромных богатств России. И. А. Корф не выпускал из поля зрения ход занятий Ломоносова в Германии, а Ломоносов со своей стороны неоднократно выражал свою благодарность Корфу за поддержку. Так, в своем письме из Марбурга от 15 сентября 1737 г. И. А. Корфу Ломоносов пишет: «... Ведь единственно лишь высокой милости Вашего превосходительства обязан я всем моим благополучием, ибо Вашим высоким заступничеством перед Ее Величеством Вы успели исходатайствовать, чтобы мне, хотя и недостоин столь значительных благодеяний, всемилостивейше дозволено было обучаться наукам в иностранных академиях» [7]. Сохранилось несколько таких писем от Ломоносова Корфу и нет сомнений, что Корф оставил в формировании Ломоносова как крупного ученого свой след. Почти такую жу роль сыграл Корф в академической карьере другого талантливого физика Г. В. Рихмана $(1711-1753)$, уроженца Пярну, бывшего наставника детей вельможи А. И. Остермана [7,8]. Ломоносов и Рихман стали друзьями, их тесное сотрудничество оказалось весьма плодотворным в развитии теории тепловых, электрических, магнитных и других физических и химических явлений.

В студенческие годы в Германии наибольшее влияние на Ломоносова оказал Х. Вольф (1679-1754) - его учитель в Марбурге, весьма именитный философ, математик и физик, почетный академик Петербургской Академии наук с времен ее основания. По своим философским взглядам Х. Вольф был сторонником Декарта и Лейбница. Рационализм и рассудительный характер картезианской философии, направленные против схоластической методологии познания, через Вольфа передались и Ломоносову. Химии и минералогии Ломоносов обучался у профессора Ю. Дюйзинга (Марбург) и у горного советника И. Генкеля - ученика и горячего сторонника создателя теории флогистона Г. В. Шталя. Пробудившийся в Петербурге у профессора физики Крафта интерес к экспериментированию превратился в Германии в глубокое убеждение, что эксперимент - это важнейший источник естественнонаучного познания и критерий правильности теоретических концепций. Высоко оценивая роль математики в обобщении данных эксперимента, Ломоносов тем самым разделяет и взгляды ньютонианцев, но он никогда в своих исследованиях не использовал понятия силы - стержня учения Ньютона о взаимодействии тел. Однако Ломоносов не стал ни картезианцем, ни ньютонианцем в полном смысле этих понятий, он разработал свой собственный метод научного познания, заключающийся в строгой экспериментально-количественной проверке положенных в основу развиваемой теории исходных гипотез. Этому совершенно правильному принципу он следовал во всех своих научных исследованиях в области естествознания и 
техники, благодаря чему развил ряд оригинальных положений по химии,

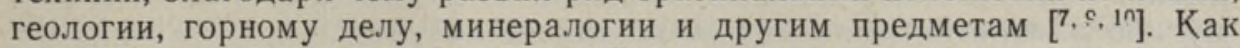
ярый противник схоластики, М. В. Ломоносов не признавал авторитетов, но в то же время в его теоретических выводах иногда четко прослеживается влияние взглядов его учителей. Так, например, в 1740-е годы, проведя ряд экспериментов, он вплотную подошел к открытию водорода и кислорода (почти на 30 лет опередив Кавендиша и Лавуазье), а тем самым к опровержению флогистонной теории. Но тем не менее полученные результаты он объяснил как типичный флогистонист. Однако, в отличие от своих учителей Дюйзинга и Генкеля, Ломоносов рассматривал флогистон не как некое невесомое мистическое начало горючести, а как весомую материальную субстанцию [3, 7].

Как известно, в середине 18 столетия одной из центральных проблем молодой физики и зарождающейся химии была природа тепла и холода. Ломоносов был одним из тех немногих крупных ученых своего времени, кто последовательно развивал стройную молекулярно-кинетическую теорию строения вещества, считая единственным источником тепловых явлений движение мельчайших частиц (корпускул) любого вещества. Правда, опираясь на явления разогрева тел при трении, он считал основой тепловых качеств только вращательное движение частиц, ошибочно пренебрегая поступательным их движением. Эта теория была опубликована на латинском языке в «Новых Комментариях Академии Наук» в 1750 г., в издании, которое получило широкое распространение и на Западе и нашло там частое реферирование. Молекулярно-кинетическая теория Ломоносова была, по понятным причинам, чисто качественной. Как мы знаем, количественные основы молекулярно-кинетической теории были разработаны лишь столетие спустя в трудах Клаузиуса, Максвелла, Больцмана и других ученых. Поскольку уровень развития химии и физики в середине 18 столетия еще не был столь высок, чтобы экспериментально проверить теорию Ломоносова на природу тепла, то вполне понятно, отчего его взгляды другими исследователями были приняты скептически. Так, в 1786 г. крупный итальянский физик А. Вольта и химик М. Скополи в своем обзоре о природе тепла писали о кинетической теории: «Это мнение, воспринятое недавно господином Макером, с чрезвычайным остроумием утверждалось также господином Ломоносовиусом» [1']. Авторы статьи, как и другие их современники, были сторонниками господствовавшей тогда теории теплорода, исходившей из существования особого невесомого вещества, носителя тепловых качеств. Даже А. Л. Лавуазье, опровергнувший на основе убедительного экспериментального материала теорию флогистона, все же включил в составленный им впервые в истории науки список истинных химических элементов теплород и светород. Еще в 20-30-х годах прошлого столетия большинство физиков и химиков того времени, включая и ведущего русского физика Г. Ф. Паррота (1767-1852), первого ректора открытого вновь в 1802 г. Тартуского университета, считали теплород и светород истөчниками тепловых и световых явлений.

В рамках своей молекулярно-кинетической теории Ломоносов вполне правильно объяснял превращения агрегатных состояний вещества, механику химических реакций между корпускулами, теплопроводность и другие явления. Кстати, будучи последовательным в своих рассуждениях, он сделал вывод о существовании и недостижимости температуры абсолютного нуля (вращательное движение частиц должно прекратиться). Однако он столкнулся с трудностями при объяснении ряда известных процессов (растворение металлов в кислотах с выделением газов, расширение некоторых тел при замерзании и др.), отчего ценная по общим основам молекулярно-кинетическая теория строения вещества Ломоносова стала порою объектом острой критики. С другой стороны, 
именно попытки опровержения теории Ломоносова современниками стимулировали развитие соответствующих исследований в истории химии. Крупными достижениями Ломоносова следует считать и экспериментальное обоснование закона сохранения массы в химических реакциях и широкое применение физических методов измерения при изучении химических явлений, что подготовило почву для возникновения современной физической химии. Как известно, им впервые в истории химии написан и опубликован на латинском языке учебник по физической химии $\left[{ }^{1-3,6}\right]$.

Свою академическую карьеру в Петербурге $M$. В. Ломоносов начал в качестве адъюнкта по химии в 1741 г. Президентом академии был в то время К. Бреверн, барон из Эстляндской губернии. В эти годы Ломоносов наряду с выполнением самых различных поручений руководства Академии начал подготовку к созданию первой в России химической лаборатории. Преодолев огромные затруднения, Ломоносову удалось открыть эту лабораторию лишь в 1748 г. Из трудов самого начального периода работы в Академии большую ценность имеет составленный и опубликованный Ломоносовым (на латинском языке) каталог минералов, имевшихся в Кунсткамере Академии, на базе которой впоследствии был основан Минералогический кабинет Академии. В середине прошлого столетия этим кабинетом руководил воспитанник Тартуского университета А. Гебель, сын старейшего профессора химии университета, члена-корреспондента Петербургской Академии наук Ф. Гебеля (17961851). В 1866 г. А. Гебель в отдельной статье дал высокую оценку труду Ломоносова как крупному достижению в развитии основ каталогизирования минералов [?].

Как уже было отмечено, к самому начальному периоду деятельности Ломоносова в Петербургской Академии наук относится знакомство и дальнейшее тесное сотрудничество с физиком Г. В. Рихманом. Семья Рихманов родом из Тарту, однако в 1710 г. отец Г. В. Рихмана Вильгельм Рихман переехал с семьей в Пярну, где умер от чумы за несколько месяцев до рождения сына. Среднее образование Г. В. Рихман получил в Таллине, в одной из старейших гимназий нашей страны; основанной в 1631 г. по инициативе шведского короля Густава II Адольфа (ныне Таллинская 1-я средняя школа). В этой гимназии Г. В. Рихман получил хорошую подготовку по математике и физике, а также по гуманитарным наукам, которые преподавал воспитанник Тартуского (Дерптского) университета А. Ф. Сигизмунди (1687-1750). Преподаватели физики и математики были последователями известного профессора математики Тартуского университета С. Димберга, одного из самых первых на Европейском континенте сторонников и пропагандистов теории Ньютона $\left[{ }^{10}\right]$.

По установленным к настоящему времени документальным данным, Рихман был единственным звеном, генеалогически связывавшим старый Тартуский университет (Academia Gustaviana Carolina) с Петербургской Академией наук в области естествознания. Вполне вероятно, что таких связующих звеньев было больше, но пока соответствующие фактические данные не найдены. Таким образом, традиции Тартуского университета определенно оказывали косвенное влияние на формирование направлений научных исследований в молодой Петербургской Академии наук и на первые работы Ломоносова в области тепла и электричества, на почве интереса к которой и произошло сближение Ломоносова и Рихмана.

Как свидетельствует вся дальнейшая научная деятельность Г. В. Рихмана в Петербургской Академии наук, он в своих тепловых и электрических исследованиях широко применял ньютоновскую методологию обобщения данных эксперимента. До завершения строительства собственной химической лаборатории М. В. Ломоносов почти все свои эксперименты по обоснованию молекулярно-кинетической теории тепла (с 
1741 по 1748 гг.) проводил в лаборатории академика Г. В. Рихмана, основоположника современной калориметрии []. Нет сомнения, что эти два крупнейших в 18 столетии ученых Петербургской Академии наук оказали друг на друга большое влияние. Так, например, Ломоносов достиг высокого уровня в изготовлении приборов и в точных измерениях температуры благодаря Рихману, а Рихман под влиянием молекулярнокинетической теории происхождения тепла Ломоносова отказался от концепции невесомого теплорода, сторонником которой он первоначально был. Их работы по атмосферному электричеству, известные во всем научном мире, были выполнены совместно [ $\left.{ }^{6}\right]$. После трагической гибели Рихмана 26 июля 1753 г. во время экспериментов по атмосферному электричеству Ломоносов остался единственным крупным ученым в России, продолжавшим исследование этих явлений. Одновременно с Рихманом и Ломоносовым изучал атмосферное электричество на острове Сааремаа другой академик Петербургской Академии наук - А. Н. Гришов, ставший впоследствии главным оппонентом Ломоносова в Академии по атмосферному электричеству [12]. Для исследования атмосферного электричества Рихман и Ломоносов изготовили оригинальный электрометр и развили собственную теорию электричества, в значительной степени подготовившую открытие закона Кулона в конще 80-х годов столетия [6, 11].

Весьма интересным является и тот факт, что Рихманом и Ломоносовым в 40-х годах 18 в. был проведен первый химический анализ состава эстонских горючих сланцев. Хотя количественные данные их работы не сохранились, все же с именами Ломоносова и Рихмана связаны первые химические исследования этого эстонского природного ископаемого. Возможно, и некоторые профессора Тартуского университета интересовались в 18 столетии природой эстонских сланцев, однако документальных данных об этом нет. Более основательный анализ химического состава эстонских сланцев был проведен в ломоносовской лаборатории академиком И. Г. Георги $(1729-1802)$ в 1792 г. В опубликованной им работе «О выгорающей земле из Ревельского (Таллинского) наместничества» $\left[{ }^{13}\right]$ приведены количественные данные о составе горючих сланцев из окрестностей Кунда. Здесь небезынтересно отметить, что всесторонний количественный анализ сланцев был осуществлен А. Шамариным в Тартуском университете под руководством крупного химика Карла Шмидта (1822-1894) в 1870 г. Можно считаь, что эти работы Ломоносова и Рихмана по эстонским горючим сланцам сыграли определенную роль в создании Ломоносовым общей теории происхождения Земли, почвы, различных минералов и рудных месторождений, опубликованной в 1763 г. в виде сочинения «О слоях земных» [14]. Он одним из первых в истории науки считал, что сланщы («шиферы») образовались из скоплений ила на дне стоячих водоемов, претерпевших изменения под влиянием высокой температуры и большого давления, и содержат различные органические остатки (раковины, рыбы, кости животных и т. д.). Он также показал органическое происхождение прибалтийского янтаря $\left[{ }^{14}\right]$.

Как свидетельствуют документальные материалы [15], М. В. Ломоносов считался в Петербургской Академии наук лучшим специалистом по определению качества и возраста природного жемчуга, интерес к которому возник у него уже в детстве. В те времена жемчуг в северных реках ловили довольно часто. Еще в середине 18 в. его порой находили и в реках Южной Эстонии в Дерптском (Тартуском) уезде в бассейне реки Гауи (Мустйыги, Пярлийыги, Салаца и др.). В 1845 г. Ломоносову было поручено оценить качество нескольких жемчужин, выловленных в реках Дерптского уезда. Ломоносов высоко оценил качество этих находок и на основании проведенной экспертизы составил соответствующую детальную инструкцию по определению возраста и качества речного 
жемчуга. Эта инструкция была размножена и на долгие годы оставалась основным рабочим документом для ловцов жемчуга в разных краях России. Интересно отметить, что почти через столетие после Ломоносова вторым признанным знатоком жемчужного дела в Петербургской Академии наук стал воспитанник Тартуского университета академик К. Э. фон Бэр $(1792-1876)$. Он составил основательный обзор о жемчуге, в котором упомянута и работа Ломоносова в этой области [15].

В 1757 г. М. В. Ломоносов был поставлен во главе Географического департамента. С его назначением это подразделение Академии наук превратилось в научный центр по картографированию территории России. Основной задачей департамента, по планам Ломоносова, было составление карт различных районов России в целях уточнения составленного ранее под руководством крупного математика Л. Эйлера атласа и издания «Нового большого атласа». Соответствующие работы велись в различных областях России, особенно интенсивно картографировались западные территории России, в частности Эстония и ее крупные острова - Сааремаа и Хийумаа $\left[{ }^{12}\right]$. Вокруг карт Эстонии, составленных под общим руководством М. В. Ломоносова, возникли у него серьезные конфликты с профессором Г. Миллером, считавшим эти карты неточными и порою даже ошибочными из-за грубых искажений в правописании наименований эстонских поселков, рек, местностей и т. д. [12]. Хотя Ломоносов всячески старался ускорить издание этих карт, их публикация задержалась, и они увидели свет лишь спустя годы после его смерти $\left[{ }^{12}\right]$. На этих картах все наименования были воспроизведены на русском и латинском языках.

Возглавляя Географический департамент, Ломоносов составил обширную программу научных экспедиций для исследования природных богатств различных областей огромной территории России. По различным причинам при жизни Ломоносова эта программа осталась нереализованной, но в течение 19 столетия его замыслы претворились в жизнь. Были организованы десятки крупных экспедиций на Кольский полуостров, в Сибирь, Среднюю Азию, Приволжье, на Дальний Восток и в другие края России. Начиная с первой половины 19 в. многие воспитанники и профессора Тартуского университета (академики Миддендорфф, Бэр, Ледебур, Бунге и др.) принимали самое активное участие в проведении таких экспедиций. Кстати, упомянутый выше профессор химии университета Ф. Гебель совместно со своим учеником К. Клаусом (17961864), открывшим в 1844 г. в Казани элемент рутений, организовал в 1834 г. экспедицию для изучения Заволжских территорий.

Заканчивая, отметим, что Таллин, Тарту и особенно Рига были основными центрами, где публиковались работы Ломоносова и труды, связанные с его именем [ $\left.{ }^{4}\right]$. Библиографической редкостью стал «Журнал старинной и новой русской литературы» (Journal der älteren und neueren russischen Litteratur), изданный в 1802 г. в Таллине И. Г. Беллинсгаузеном и содержащий вторую по хронологической последовательности биографию М. В. Ломоносова. В этой биографии в основном освещена литературная деятельность Ломоносова, но дан и краткий обзор его достижений в области естественных наук, в том числе и в химии. Это издание распространилось и в Западной Европе и стало ценным биографическим источником русского ученого-энциклопедиста для западного читателя. В 1823 г. в Тарту и Риге был напечатан сборник «Антология русской поэзии», куда вошли лучшие оды и поэмы Ломоносова в немецком переводе. Таких примеров можно привести много. В конце 19 столетия имя М. В. Ломоносова встречается и на страницах эстонских газет и учебников.

Отметим еще, что начатая $M$. В. Ломоносовым важнейшая работа по созданию научной русской химической терминологии была поднята в 
начале 19 в. на новый уровень профессором химии Тартуского университета А. Шерером $(1771-1824)$, ставшим впоследствии академиком Петербургской Академии наук, и воспитанником химической лаборатории Ломоносова академиком В. М. Севергиным (1765-1826). Они впервые приспособили французскую химическую терминологию Лавуазье к специфике русского языка. Впоследствии эта работа была продолжена другим воспитанником Тартуского университета - академиком Г. Гессом $(1802-1850)$, основоположником термохимии $\left[{ }^{16}\right]$.

\section{Л ИТЕРАТ У РА}

1. Меншуткин Б. Н. Жизнеописание Михаила Васильевича Ломоносова. М.-Л., 1937.

2. Менцуткин Б. Н. М. В. Ломоносов как физико-химик. - Изв. Санкт-Петерб. политехн. ин-та, 1904, 1, вып. $1-2$ и $3-4$.

3. Меншуткин Б. H. Жизнь и деятельность Николая Александровича Меншуткина. СПб, 1908.

4. Городинская Р. Б. Издание работ М. В. Ломоносова и литературы о нем в Прибалтике до начала XX века. - В кн.: Из истории естествознання и техники Прибалтики, 3. Рига, 1971, 35-46.

5. ҚБогачев В. В. Ломоносов - первый русский геолог. - Сб. Уч. лит. общ-ва при Юрьевском ун-те, 1912, 199, 11-28.

6. Кононков А. Ф., Спасский Б. И. М. В. Ломоносов как физик. М., 1961.

7. Страдынь Я. П., Валескалн П. И. И. А. Корф - президент Петербургской академии наук (к 200-летию со дня смерти). - В кн.: Из истории естествознания и техники Прибалтики, 1. Рига, 1968, 65-79.

8. Цверава $Г$. К. Новые материалы к биографии Г. В. Рихмана. - В кн: Из истории естествознания и техники Прибалтики, 5. Рига, 1976, 28-36.

9. Гордеев Д. И. М. В. Ломоносов - основоположник геологической науки. М., 1961.

10. История Тартуского университета $(1632-1982)$. Таллин, 1983.

11. Дорфман Я. Г. Всемирная история физики (с древнейших времен до конца XVIII века). М., 1974.

12. Varep, E. Eesti atlasest. - Rmt.: Teaduse ajaloo lehekülgi Eestis, I. Tallinn, 1968, 193-207.

13. Кострин К. В., Раскин Н. М. Петербургский академик И. Г. Георги - пионер изучения эстонских горючих сланцев. - В кн.: Из истории естествознания и техники Прибалтики, 4. Рига, 1972, 11-14.

14. Ломоносов М. О слоях земных и другие работы по геологин. М.-Л., 1949.

15. Уханова И. Н. М. В. Ломоносов и лифляндский жемчуг. - В кн.: Из истории естествознания и техники Прибалтики, 4. Рига, 1972, 5-9.

16. Palm, U. Keemia arengujooni Tartu ülikoolis 1802-1918. - Rmt.: Tartu Riikliku Úlikooli keemiaosakond 1947-1972. Tartu, 1972, 5-39.

Тартуский государственный университет
Поступила в редакцию 29/X 1986 